\title{
Antioxidant and hepatoprotective effects of Garcinia indica fruit rind in antitubercular drug-induced liver injury in rats
}

This article was published in the following Dove Press journal:

Botanics:Targets and Therapy

26 March 2013

Number of times this article has been viewed

\author{
Vandana S Panda' \\ Hardik D Ashar' \\ Anita Sharan ${ }^{2}$ \\ 'Department of Pharmacology and \\ Toxicology, Prin KM Kundnani \\ College of Pharmacy, Colaba, Mumbai, \\ India; ${ }^{2}$ Department of Pathology, \\ Dr DY Patil Medical College, Nerul, \\ Navi Mumbai, India
}

\begin{abstract}
The protective effects of aqueous extracts of the fruit rind of Garcinia indica (GIE) in antitubercular drug (ATD)-induced liver injury were investigated in rats. GIE $(400 \mathrm{mg} / \mathrm{kg}$ and $800 \mathrm{mg} / \mathrm{kg}$ ) and the reference drug Liv.52 (500 mg/kg) were administered orally for 29 days to ATD (isoniazid $7.5 \mathrm{mg} / \mathrm{kg}$, rifampicin $10 \mathrm{mg} / \mathrm{kg}$, and pyrazinamide $35 \mathrm{mg} / \mathrm{kg}$ )-treated rats. GIE attenuated significantly the ATD-elevated levels of aspartate aminotransferase, alanine transaminase, alkaline phosphatase, bilirubin, and malondialdehyde and restored the ATDdepleted levels of glutathione (GSH), superoxide dismutase, catalase, GSH peroxidase, and GSH reductase. The present findings indicate that the hepatoprotective effect of GIE in ATDinduced oxidative damage may be due to its antioxidant activity.

Keywords: Garcinia indica fruit, antitubercular drugs, Liv.52, hepatoprotective, antioxidant activity
\end{abstract}

\section{Introduction}

Tuberculosis (TB) continues to remain a significant infectious disease across much of the developing world, and spreads rapidly amongst people in low socio-economic groups. More people in the developing world contract TB because of compromised immunity, largely due to high rates of HIV infection and the corresponding development of AIDS. ${ }^{1}$ Co-infection with HIV increases the risk of TB six- to 50-fold. ${ }^{2}$ Antitubercular drugs (ATDs) such as isoniazid, rifampicin, and pyrazinamide have been a mainstay in the treatment of TB. Although a vast majority of patients tolerate the drugs, some develop adverse effects, of which hepatotoxicity is the most serious one and becomes fatal if not recognized early and when therapy is not interrupted in time. ${ }^{3}$

In the absence of suitable hepatoprotectants in modern medicine, the search for a herbal hepatoprotectant continues. Garcinia indica Choisy (family: Clusiaceae/ Guttiferae), a slender evergreen tree, is endemic to the west coast of India. ${ }^{4}$ It has many culinary, pharmaceutical, and industrial uses. The dried rind, known as "kokum," is an Indian spice and condiment used in many parts of the country for making several curry preparations. Syrup made from the fruits is a healthy soft drink used during the summer to relieve sunstroke. Many therapeutic effects of the fruit have been described in Ayurveda, which include its usefulness as an infusion for skin ailments such as rashes caused by allergies; in treatment of burns, scalds, and chafed skin; as a remedy for dysentery and mucous diarrhea; as an appetizer and a good liver tonic; as a cardiotonic; and for bleeding, piles, dysentery, tumors, and heart diseases. ${ }^{5}$

One of the ingredients of kokum, hydroxycitric acid, has been patented for use as a hypocholesterolemic agent. ${ }^{6}$ Another constituent from G. indica, garcinol, 
a polyisoprenylated benzophenone, has been reported to be an antioxidant, ${ }^{7,8}$ a glycation inhibitor, ${ }^{9}$ and an antiulcer agent. ${ }^{10}$ It possesses a strong growth-inhibitory effect against human leukemia HL-60 cells. ${ }^{11}$ Garcinol also shows antibacterial activity against methicillin-resistant Staphylococcus aureus, which is comparable with that of the antibiotic vancomycin. $^{12,13}$ It is a natural histone acetylasetransferase inhibitor both in vitro and in vivo, suggesting its implication in a wide variety of diseases like cancer and AIDS. ${ }^{14,15}$ Apart from hydroxycitric acid and garcinol, kokum contains other compounds like citric acid, malic acid, polyphenols, anthocyanin pigments, and ascorbic acid with potent antioxidant properties. ${ }^{16}$

Traditionally, the syrup of $G$. indica has been administered to alcohol-intoxicated individuals for protection of the liver. Literature reports the aqueous extracts of $G$. indica to possess potent antioxidant, free-radical scavenging and antilipid peroxidative activities. ${ }^{7}$ Promising results of our previous studies on the hepatoprotective effect of $G$. indica fruit in carbon tetrachloride-induced hepatotoxicity in rats ${ }^{17}$ encouraged us to undertake this study. With this background, the present study was carried out to investigate the hepatoprotective effect and a possible underlying antioxidant activity of aqueous extracts of the fruit rind of $G$. indica by assaying various marker enzymes, antioxidant enzymes, and glutathione (GSH) in chronically ATD-fed rats.

\section{Materials and methods}

\section{Plant material}

The fruit rinds of $G$. indica were collected from the Konkan region of Maharashtra, India and air-dried under shade, powdered mechanically, and stored in airtight containers. The powder was extracted in a soxhlet apparatus using water as a solvent, and the extract obtained was stored in a refrigerator for further use. The plant was authenticated at the Blatter Herbarium (St Xavier's College, Mumbai, India) after matching with the existing specimen (Accession No 03587).

\section{Drugs and chemicals}

A gift sample of isoniazid was obtained from Amsal Chem Pvt Ltd (Mumbai, India). Rifampicin and pyrazinamide gift samples were provided by Sandoz Pvt Ltd (Mumbai, India). Liv.52 tablets manufactured by the Himalaya Drug Company (Bangalore, India) were purchased from the local chemist. Thiobarbituric acid (TBA), reduced GSH, oxidized GSH (GSSG), and nicotinamide adenine dinucleotide phosphate (NADPH) were obtained from HiMedia Laboratories (Mumbai, India). Epinephrine and 5, 5'-dithiobis (2-nitrobenzoic acid) (DTNB) were purchased from Sigma Chemical Co (St Louis, MO). All other chemicals were obtained from local sources and were of analytical grade.

\section{Experimental animals}

Wistar albino rats (150-200 g) of either sex were used. They were housed in clean polypropylene cages under standard conditions of humidity $(50 \% \pm 5 \%)$, temperature $\left(25^{\circ} \mathrm{C} \pm 2{ }^{\circ} \mathrm{C}\right)$, and light (12 hours light/12 hours dark cycle) and fed with a standard diet (Amrut Lab Animal Feed, Pune, India) and water ad libitum. All animals were handled with humane care. Experimental protocols were reviewed and approved by the Institutional Animal Ethics Committee (Animal House Registration No 25/1999/CPCSEA) and conformed to the Indian National Science Academy Guidelines for the Use and Care of Experimental Animals in Research.

\section{Preparation of test and reference drug solutions}

G. indica extract was dissolved in distilled water (GIE), and the aqueous solution was used. Isoniazid and pyrazinamide were dissolved in distilled water, whereas rifampicin was first dissolved in dilute hydrochloric acid and later added to the isoniazid and pyrazinamide mixture. This mixture of ATDs was administered to rats immediately after preparation. Liv.52 tablets were powdered and suspended in distilled water using $1 \% \mathrm{w} / \mathrm{v}$ carboxymethyl cellulose and administered.

\section{Experimental procedure ${ }^{17-19}$}

The animals, after acclimatization (6-7 days) in the animal quarters, were randomly divided into five groups of six animals each and treated in the following manner:

- Group I served as normal control and received an aqueous solution of $1 \% \mathrm{w} / \mathrm{v}$ carboxymethyl cellulose $(1 \mathrm{~mL} / \mathrm{kg})$ orally (p.o.) once daily for 29 days.

- Group II served as toxicant control and received a mixture of ATD (p.o.) once daily for 29 days.

- Group III, termed GIE400, received GIE (400 mg/kg, p.o.) and ATD (p.o.) both once daily for 29 days.

- Group IV, termed GIE800, received GIE (800 mg/kg, p.o.) and ATD (p.o.) both once daily for 29 days.

- Group V served as standard control and received Liv.52 tablets (500 mg/kg, p.o.) and ATD (p.o.) both once daily for 29 days.

All the animals were humanely sacrificed using ether 24 hours after the last dose administration. Blood (3-4 mL) was collected by cardiac puncture under light ether anesthesia 
and allowed to clot for 30 minutes at room temperature. Serum was separated by centrifugation in a refrigerated tabletop centrifuge at $1200 \times \mathrm{g}$ at $30^{\circ} \mathrm{C}$ for 15 minutes, and used for the estimation of marker enzymes (aspartate aminotransferase [AST], alanine transaminase [ALT], alkaline phosphatase $[\mathrm{ALP}]$ ), albumin (Alb), total proteins (TP), and serum bilirubin (BILI). The livers were dissected immediately, washed with ice-cold saline, and divided into two parts. One part was used to prepare a $10 \%(\mathrm{w} / \mathrm{v})$ homogenate in $1.15 \%$ potassium chloride. An aliquot of the homogenate was used for the determination of lipid peroxidation (LPO). The homogenates were centrifuged in a refrigerated tabletop centrifuge at $7000 \times \mathrm{g}$ for 10 minutes at $4{ }^{\circ} \mathrm{C}$, and the supernatants were used for the assays of $\mathrm{GSH}$, superoxide dismutase (SOD), catalase (CAT), glutathione peroxidase (GPx), and glutathione reductase (GR). The remaining part of the liver was fixed in $10 \%(\mathrm{w} / \mathrm{v})$ buffered formalin and used for histological studies.

\section{Marker enzyme assays}

The liver marker enzymes AST, ALT, and ALP were assayed in serum using standard kits supplied from Span Diagnostics (Surat, India).

\section{Protein estimation}

The levels of TP and Alb were determined in the serum of experimental animals by using the Lowry et $\mathrm{al}^{20}$ method and the bromocresol green method, respectively. ${ }^{21}$ Kits purchased from Span Diagnostics were used for the estimation of Alb.

\section{Bilirubin estimation}

Level of BILI was determined by the Jendrassik and Grof ${ }^{22}$ method. Kits were supplied by Accurex Ltd (Mumbai, India).

\section{Lipid peroxidation}

The quantitative estimation of LPO was performed by determining the concentration of TBA-reactive substances in the liver using the method of Ohkawa et $\mathrm{a}^{23}$. The amount of malondialdehyde (MDA) formed was quantified by reaction with TBA and used as an index of LPO. The results were expressed as nanomole of MDA per gram of wet tissue using the molar extinction coefficient of the chromophore $\left(1.56 \times 10^{-5} / \mathrm{M} / \mathrm{cm}\right)$ and 1,1,3,3-tetraethoxypropane as standard.

\section{GSH estimation}

GSH was estimated in the liver homogenate using DTNB by the method of Ellman. ${ }^{24}$ The absorbance was read at $412 \mathrm{~nm}$, and the results were expressed as micromole per gram of wet tissue.

\section{Antioxidant enzyme assays in liver homogenate}

SOD was assayed by the method of Sun and $\operatorname{Zigman}^{25}$ in which the activity of SOD was inversely proportional to the

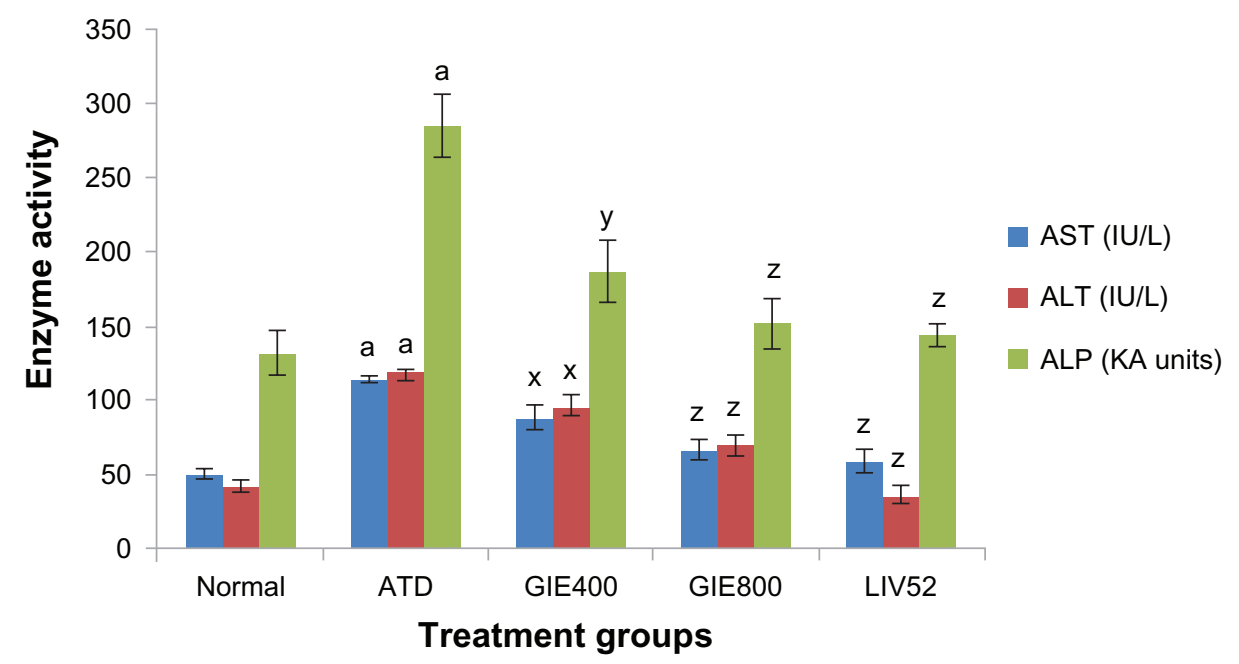

Figure I Effect of GIE on serum enzymes (AST, ALT, and ALP) in ATD-intoxicated rats.

Notes: Values are mean \pm standard error of the mean; $N=6$ in each group. $P$-values are mean \pm standard error of the mean for six animals in each group. $P$-value ${ }^{a}<0.00$ I when toxicant control compared with normal control, ${ }^{x}<0.05 ; y<0.01 ;{ }^{z}<0.001$ when experimental groups compared with toxicant control.

Abbreviations: ALP, alkaline phosphatase; ALT, alanine transaminase; AST, aspartate aminotransferase; ATD, antitubercular drugs; GIE, aqueous extracts of the fruit rind of Garcinia indica. 


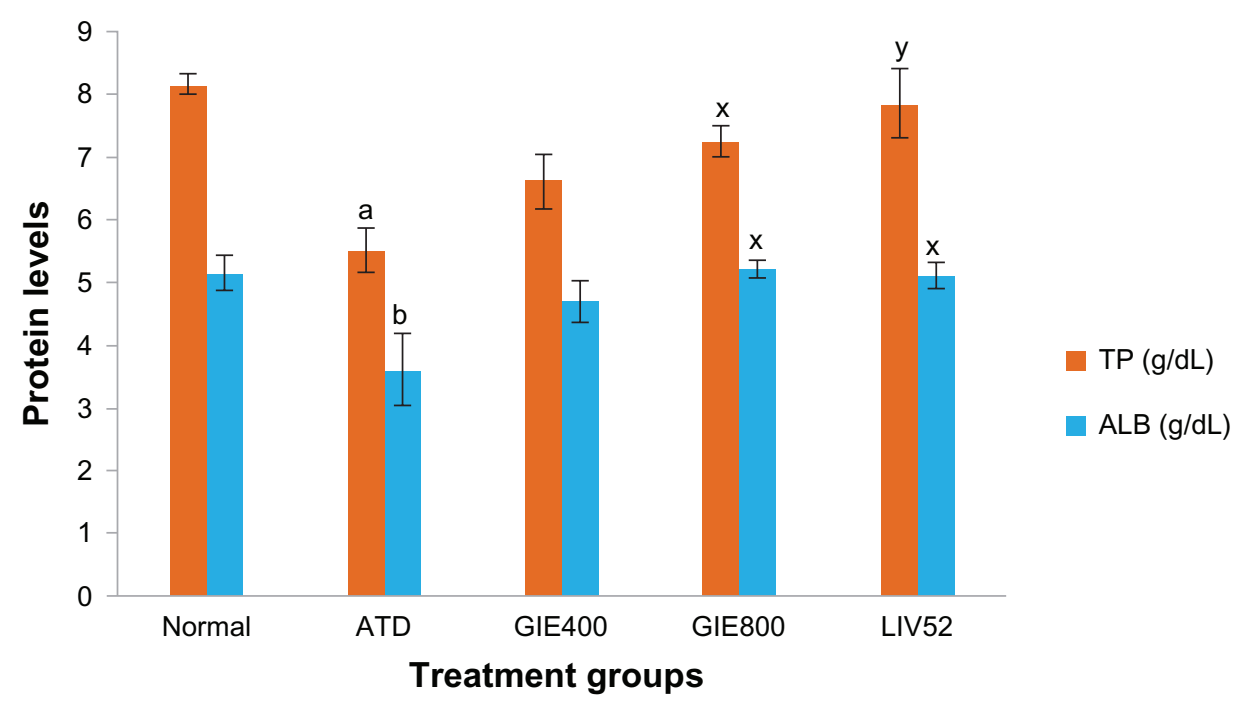

Figure 2 Effect of GIE on serum albumin and total protein in ATD-intoxicated rats.

Notes: Values are mean \pm standard error of the mean; $N=6$ in each group. $P$-values are mean \pm standard error of the mean for six animals in each group. $P$-values: ${ }^{a}<0.001$; ${ }^{b}<0.05$ when toxicant control compared with normal control, ${ }^{x}<0.05 ;{ }^{y}<0.01$ when experimental groups compared with toxicant control.

Abbreviations: ATD, antitubercular drugs; GIE, aqueous extracts of the fruit rind of Garcinia indica.

concentration of its oxidation product adrenochrome, which was measured spectrophotometrically at $320 \mathrm{~nm}$. One unit of SOD activity is defined as the enzyme concentration required to inhibit the rate of auto-oxidation of epinephrine by $50 \%$ in 1 minute at $\mathrm{pH} 10$.

CAT was estimated by the method of Clairborne, ${ }^{26}$ which is a quantitative spectroscopic method developed for following the breakdown of hydrogen peroxide $\left(\mathrm{H}_{2} \mathrm{O}_{2}\right)$ at $240 \mathrm{~nm}$ in unit time for routine studies of CAT kinetics.

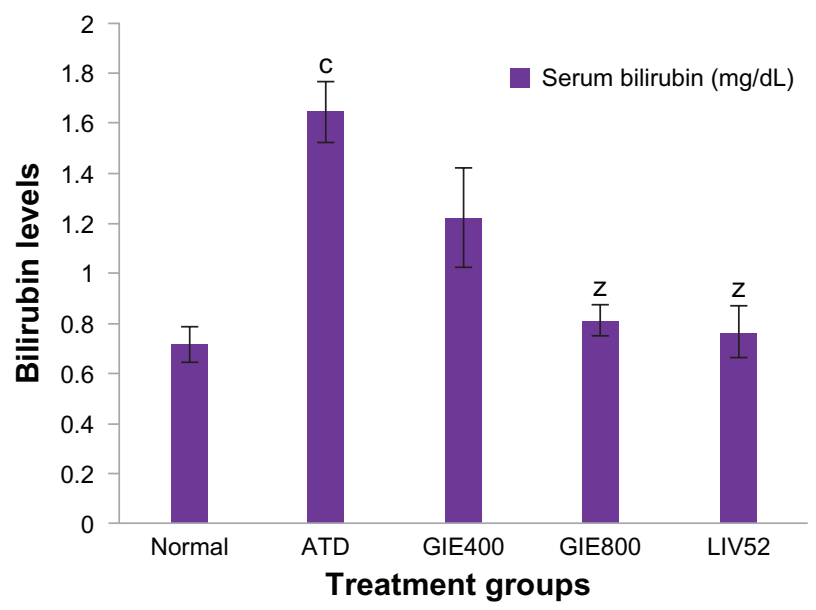

Figure 3 Effect of GIE on serum bilirubin in ATD-intoxicated rats.

Notes: Values are mean \pm standard error of the mean; $N=6$ in each group. $P$-values are mean \pm standard error of the mean for six animals in each group. $P$-values: ${ }^{c}<0.05$ when toxicant control compared with normal control, ${ }^{z}<0.00$ I when experimental groups compared with toxicant control.

Abbreviations: ATD, antitubercular drugs; GIE, aqueous extracts of the fruit rind of Garcinia indica.
GPx estimation was carried out using the method of Rotruck et al, ${ }^{27}$ which makes use of the following reaction:

$$
\mathrm{H}_{2} \mathrm{O}_{2}+2 \mathrm{GSH} \rightarrow 2 \mathrm{H}_{2} \mathrm{O}+\mathrm{GSSG} \text { (oxidized glutathione). }
$$

GPx in the tissue homogenate oxidizes GSH, and simultaneously $\mathrm{H}_{2} \mathrm{O}_{2}$ is reduced to water. This reaction is arrested at 10 minutes using trichloroacetic acid, and the remaining GSH is reacted with DTNB solution to result in a colored compound, which is measured spectrophotometrically at $420 \mathrm{~nm}$.

GR activity was determined using the method of Mohandas et al, ${ }^{28}$ in which the following reaction is implicated:

$$
\mathrm{NADPH}+\mathrm{H}^{+}+\mathrm{GSSG} \rightarrow \mathrm{NADP}^{+}+2 \mathrm{GSH} .
$$

In the presence of GR, GSSG undergoes reduction, and simultaneously NADPH is oxidized to $\mathrm{NADP}^{+}$. Enzyme activity is quantified at room temperature by measuring the disappearance of NADPH/min spectrophotometrically at $340 \mathrm{~nm}$.

\section{Histopathological studies}

The parts of livers that were stored in 10\% (w/v) buffered formalin were embedded in paraffin, and the sections cut at $5 \mu \mathrm{m}$ and stained with hematoxylin and eosin. These sections were then examined under a light microscope for histoarchitectural changes. 
Table I Effect of GIE on liver TBARS, GSH, SOD, CAT, GPx, and GR in ATD-intoxicated rats

\begin{tabular}{|c|c|c|c|c|c|}
\hline Biochemical parameters & $\begin{array}{l}\text { Group I } \\
\text { Normal control I\% } \\
\text { cmc in water }\end{array}$ & $\begin{array}{l}\text { Group II } \\
\text { Toxicant control } \\
\text { ATD }\end{array}$ & $\begin{array}{l}\text { Group III } \\
\text { GIE (400 mg/kg) }\end{array}$ & $\begin{array}{l}\text { Group IV } \\
\text { GIE (800 mg/kg) }\end{array}$ & $\begin{array}{l}\text { Group V } \\
\text { Liv.52 } \\
(500 \mathrm{mg} / \mathrm{kg})\end{array}$ \\
\hline $\begin{array}{l}\text { TBARS (nmol MDA/mg } \\
\text { protein) }\end{array}$ & $0.28 \pm 0.04$ & $1.31 \pm 0.16^{\mathrm{a}}$ & $0.93 \pm 0.08^{x}$ & $0.47 \pm 0.07^{z}$ & $0.37 \pm 0.02^{z}$ \\
\hline GSH ( $\mu \mathrm{mol} / \mathrm{mg}$ protein) & $5.09 \pm 0.45$ & $2.35 \pm 0.55^{b}$ & $3.53 \pm 0.29$ & $4.3 \pm 0.39^{x}$ & $5.18 \pm 0.52^{y}$ \\
\hline SOD (U/mg protein) & $12.35 \pm 1.04$ & $5.52 \pm 1.30^{\mathrm{b}}$ & $10.81 \pm 0.76^{x}$ & $11.76 \pm 1.39 y$ & $11.95 \pm 1.28^{y}$ \\
\hline CAT (U/mg protein) & $75.34 \pm 4.57$ & $39.92 \pm 2.79^{a}$ & $65.9 \pm 3.0^{x}$ & $72.04 \pm 3.43^{y}$ & $72.53 \pm 8.99 y$ \\
\hline GPx (U/mg protein) & $11.57 \pm 0.27$ & $7.17 \pm 0.32^{\mathrm{a}}$ & $8.35 \pm 0.35$ & $10.52 \pm 0.50^{z}$ & $11.12 \pm 0.84^{z}$ \\
\hline GR (U/mg protein) & $115.45 \pm 4.55$ & $82.89 \pm 5.00^{\mathrm{a}}$ & $95.62 \pm 5.15$ & $115.30 \pm 5.14^{z}$ & $116.12 \pm 1.75^{z}$ \\
\hline
\end{tabular}

Notes: Values are mean \pm standard error of the mean; $N=6$ in each group. $P$-values: ${ }^{a}<0.001 ;{ }^{b}<0.01$ when toxicant control compared with normal control, ${ }^{\times}<0.05 ;{ }^{y}<0.01$, ${ }^{z}<0.00$ I when experimental groups compared with toxicant control. One unit of CAT $=\mu \mathrm{mol}$ hydrogen peroxide consumed $/ \mathrm{min} / \mathrm{mg} \mathrm{protein}$. One unit of GPx $=\mu \mathrm{g}$ GSH utilized $/ \mathrm{min} / \mathrm{mg}$ protein. One unit of $\mathrm{GR}=\mathrm{nmol}$ nicotinamide adenine dinucleotide phosphate oxidized $/ \mathrm{min} / \mathrm{mg}$ protein.

Abbreviations: ATD, antitubercular drugs; CAT, catalase; cmc, carboxymethyl cellulose; GPx, glutathione peroxidase; GR; glutatione reductase; GSH, glutathione; GIE, aqueous extracts of the fruit rind of Garcinia indica; MDA, malondialdehyde; SOD, superoxide dismutases; TBARS, thiobarbituric acid reactive substances.

\section{Statistical analysis}

The results of hepatoprotective and antioxidant activities are expressed as mean \pm standard error of the mean. Results were statistically analyzed using one-way analysis of variance, followed by the Tukey-Kramer post test for individual comparisons. $P<0.05$ was considered to be significant.

\section{Results}

\section{Biochemical parameters}

The effects of GIE on serum marker enzymes AST, ALT, and ALP; serum proteins Alb and TP; and BILI are summarized in Figures 1-3, respectively. Significant elevation in the marker enzyme activities and bilirubin levels $(P<0.001$ and $P<0.05)$ and significant depletion in Alb and TP levels $(P<0.05$ and $P<0.001)$ was observed in the ATD-treated group of rats when compared with the normal group of rats. Treatment with GIE400, GIE800, and Liv.52 to rats intoxicated with ATD significantly attenuated $(P<0.05$,

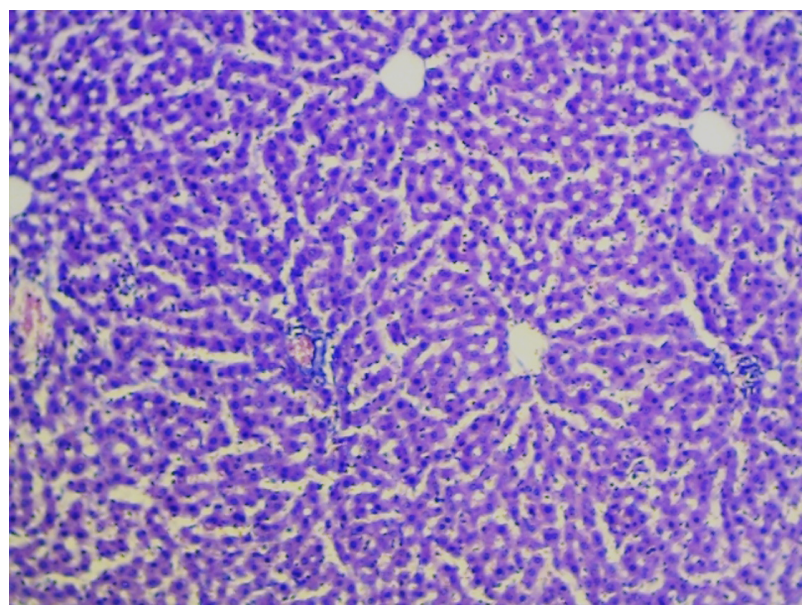

Figure 4 Hematoxylin and eosin staining of liver tissue of normal rats $10 \times$ $10 x=100 x$.
$P<0.001$, and $P<0.001$, respectively) the ATD-elevated activities of AST and ALT. The same treatment decreased significantly $(P<0.01, P<0.001$, and $P<0.001)$ the ATD-elevated activity of ALP. ATD-depleted serum Alb levels were restored significantly $(P<0.05)$ by GIE800 treatment, which was comparable with Liv.52 treatment. ATD treatment significantly $(P<0.001)$ decreased serum TP levels, which were significantly restored $(P<0.05$ and $P<0.01)$ by GIE 800 and Liv.52. The BILI level depleted by ATD treatment $(P<0.05)$ was also significantly restored by GIE800 $(P<0.001)$, which was comparable with Liv.52.

The effects of GIE on antioxidant enzymes, GSH, and LPO are summarized in Table 1. MDA, the LPO marker, was significantly elevated $(P<0.001)$ in the ATD control group of rats when compared with the normal group. Treatment of GIE400, GIE800, and Liv.52 to ATD-treated rats depleted significantly $(P<0.05, P<0.001$, and $P<0.001$, respectively) the increased levels of MDA.

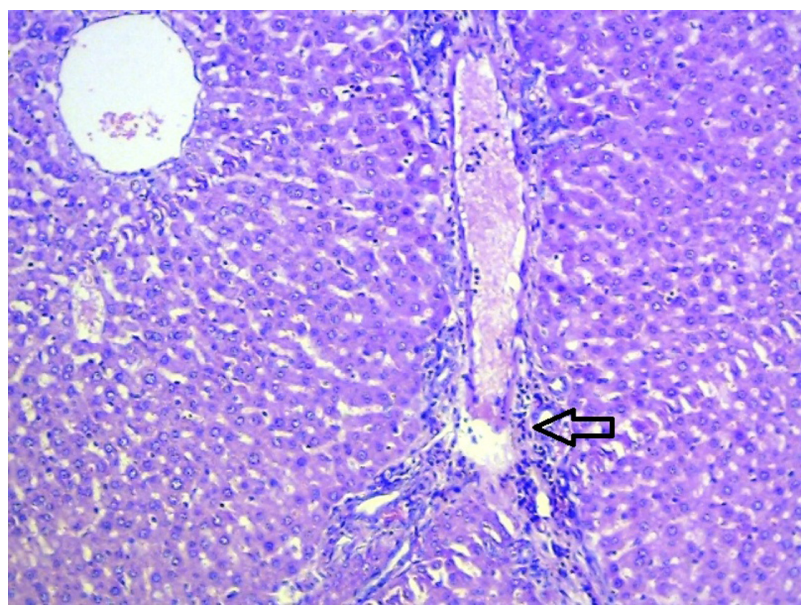

Figure 5 Hematoxylin and eosin staining of liver tissue of antitubercular drugtreated rats $10 \times 10 x=100 x$. 


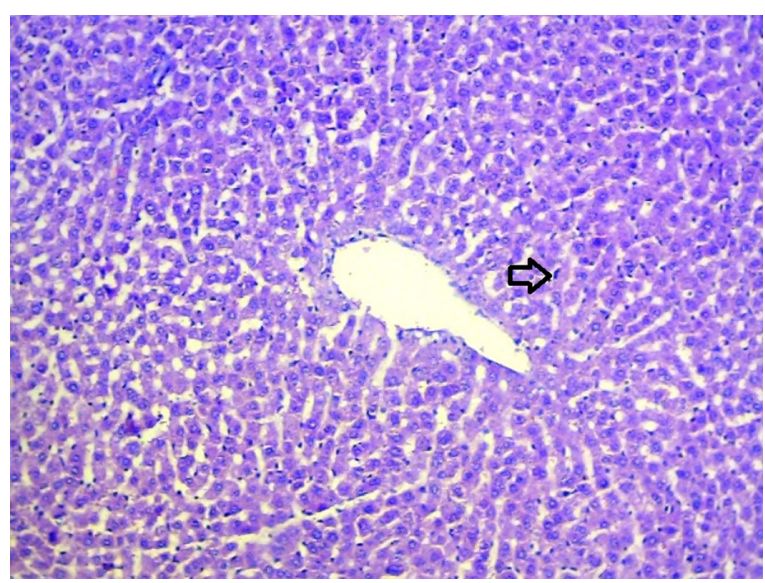

Figure 6 Hematoxylin and eosin staining of liver tissue of rats treated with antitubercular drugs and Liv.52 $(500 \mathrm{mg} / \mathrm{kg}) 10 \times 10 \mathrm{x}=100 \mathrm{x}$.

Significant decline in GSH levels $(P<0.01)$ was observed in the ATD-treated group when compared with the normal control group of rats. Treatments with GIE800 and Liv.52 restored significantly $(P<0.05$ and $P<0.01)$ the GSH levels depleted by ATD.

Liver SOD and CAT activities were examined to be noticeably lower $(P<0.01$ and $P<0.001)$ in ATD-treated rats when compared with normal rats. Treatments with GIE400, GIE800, and Liv.52 significantly $(P<0.05, P<0.01$, and $P<0.01)$ restored the ATD-depleted SOD and CAT activities.

GPx and GR activities were depleted significantly $(P<0.001)$ by ATD treatment. Treatments with GIE800 and Liv.52 restored significantly $(P<0.001)$ the ATD-depleted GPx and GR activities.

\section{Histopathological studies}

The livers of rats of the normal group showed normal histology with no significant change in the cellular structure and

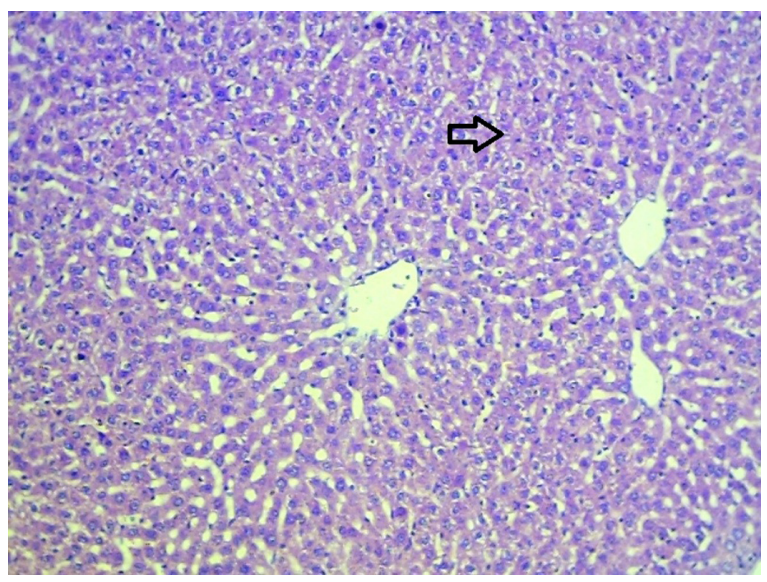

Figure 7 Hematoxylin and eosin staining of liver tissue of rats treated with antitubercular drugs and Garcinia indica extract $(400 \mathrm{mg} / \mathrm{kg}) 10 \times 10 \mathrm{x}=100 \mathrm{x}$.

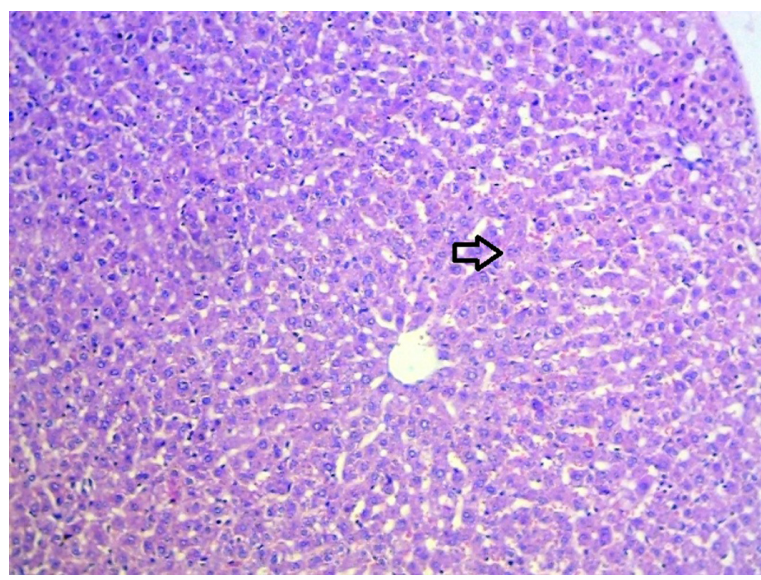

Figure 8 Hematoxylin and eosin staining of liver tissue of rats treated with antitubercular drugs and Garcinia indica extract $(800 \mathrm{mg} / \mathrm{kg}) 10 \times 10 \mathrm{x}=100 \mathrm{x}$.

architecture (Figure 4). The liver sections of ATD-treated rats showed parenchyma with flaccid architecture. The central vein showed congestion with focal congestion of sinusoids. Also observed were cloudy swelling and marked diffuse granular degeneration accompanied by occasional fields of mid-zone necrosis (Figure 5). Marked periportal lymphocytic infiltration was noted in the livers of this group of rats. Liv.52-treated rat livers exhibited almost normal histology with minimal diffuse granular degeneration, minimal multifocal periportal lymphocytic infiltration, and minimal Kupffer cell hyperplasia (Figure 6). Congestion was also minimal. GIE400-treated livers showed moderate granular degeneration and mild diffuse lymphocytic infiltration (Figure 7). GIE800-treated livers were comparable with Liv.52 in histology and general architecture (Figure 8). These liver sections showed minimal diffuse granular degeneration and minimal diffuse leukocytic infiltration. Histoarchitecture of GIE800 was more toward normal as compared with GIE400, whereas Liv.52-treated rats showed almost normal histology.

\section{Discussion and conclusion}

In the present study, the G. indica fruit was evaluated for hepatoprotective activity using ATD-induced liver injury in rats. ATD-induced liver injury encompasses a wide spectrum of liver injury ranging from asymptomatic minimal elevation of liver enzymes to acute liver failure, often leading to death or liver transplantation. Indeed, it is a leading cause of drug-induced liver injury and of drug-induced acute liver failure leading to death. ${ }^{29}$ Furthermore, the ripple effects of hepatotoxicity include disruption of treatment with potential for prolongation of treatment, genesis of drug resistance, and suboptimal cure. 
The ATDs isoniazid, rifampicin, and pyrazinamide used in this study are each potentially toxic individually, and when given in a combination their toxic effects are enhanced in a synergistic manner. In its metabolic pathway, isoniazid is first converted to acetylisoniazid, which, on hydrolysis, yields acetylhydrazine. The conversion of acetylhydrazine to a toxic metabolite via cytochrome P450 leads to hepatotoxicity. ${ }^{18}$ Rifampicin induces cytochrome P450 enzymes, causing an increased production of toxic metabolites from acetylhydrazine. ${ }^{30}$ Rifampicin can also increase the metabolism of isoniazid to isonicotinic acid and hydrazine, both of which are hepatotoxic. ${ }^{31}$ The plasma half-life of acetylhydrazine is shortened by rifampicin, and acetylhydrazine is quickly converted to its toxic metabolites, which is related to the higher incidence of liver necrosis caused by isoniazid and rifampicin in combination. ${ }^{32}$ Pyrazinamide in combination with those drugs is also associated with an increased incidence of hepatotoxicity. ${ }^{33}$

ATD therapy is continued for a long period and, thus, a chronic model of study is essential to mimic hepatotoxicity. AST and ALT are well-known diagnostic indicators of liver disease. In cases of liver damage with hepatocellular lesions and parenchymal cell necrosis, these marker enzymes are released from the damaged tissues into the blood stream in conformity with the extent of liver damage. The elevated activities of these marker enzymes in ATD-treated rats in the present study were due to the extensive liver damage caused by these drugs. Treatment with the test drug GIE (in both doses), as well as the reference drug Liv.52, significantly reduced the elevation in liver enzymes.

ALP activity was found to increase in the animals treated with ATD. ${ }^{34}$ ALP activity on endothelial cell surfaces is responsible for the conversion of adenosine nucleotides to adenosine, a potent vasodilator and anti-inflammatory mediator that results from injury. So, following injury, accumulation of interleukin- 6 can lead to production of adenosine by ALP and subsequent protection from ischemic injury. This may be the reason for the increment in ALPintoxicated rats that have cell necrosis. Co-administration of GIE deactivates the reactive metabolites (which damage the liver cells) formed by the ATD regimen, suggesting the membrane-stabilizing action of GIE.

Alterations in protein metabolism have been considered for decades to be one of the conditions associated with hepatic dysfunction. ${ }^{35}$ Our results showed decreased levels of protein in the serum of ATD-administered rats as compared with the control group, which is restored to almost normal by GIE treatment. The disassociation of polyribosomal profiles from endoplasmic reticulum following ATD administration is associated with the inhibition of protein synthesis, which may be partially responsible for the fatty liver, but probably not necrosis, although it contributes to disabling of the cell. ${ }^{36}$

Bilirubin, a major breakdown product that results from the destruction of red blood cells, is removed from the blood by the liver through conjugation and secreted into the bile. It usually becomes elevated as a result of decreased uptake by the liver, decreased conjugation, decreased secretion from the liver, or blockage of the bile ducts, which happens in liver damage. Consumption of ATD increased the bilirubin level in the serum of the ATD-treated rats. ${ }^{37}$ Co-administration of GIE restored the level of bilirubin to near normal by its cytoprotectivity, and may also be due to an inhibitory effect on cytochrome P-450.

ATD-induced hepatitis is due to the biotransformation of isoniazid, rifampicin, and pyrazinamide to their respective reactive metabolites, which are capable of binding to cellular macromolecules. ${ }^{18,19,38}$ As an alternative to inducing cellular damage by covalent binding, peroxidation of endogenous lipids has been shown to be a major factor in the cytotoxic action of isoniazid and rifampicin. There is evidence that these ATDs cause cellular damage through the induction of oxidative stress, which is generally attributed to the formation of the highly reactive oxygen species, which act as stimulators of LPO and a source for destruction and damage to the cell membrane ${ }^{38}$ An increase in the level of LPO in ATDtreated livers reflected the hepatocellular damage. Treatment with GIE significantly reversed these changes. Hence, it is likely that the mechanism of hepatoprotection of GIE is its antioxidant activity.

The toxic metabolites of the ATDs bind to and damage cellular macromolecules in the liver, which contains antioxidant enzymes such as SOD, CAT, GPx, and GR. ${ }^{39}$ It is well known that SOD, CAT, GPx, and GR constitute a mutually supportive team of antioxidant enzymes that provide a defense system against reactive oxygen species..$^{40}$ In the present study, SOD activity decreased significantly in ATD-treated animals, due to an excessive formation of superoxide anions. The activities of $\mathrm{H}_{2} \mathrm{O}_{2}$-scavenging enzymes CAT and GPx also decreased significantly after ATD treatment. The decline in these enzyme activities can be explained by the fact that excessive superoxide anions may inactivate SOD, thus resulting in an inactivation of the $\mathrm{H}_{2} \mathrm{O}_{2}$-scavenging enzymes. Concomitant administration of GIE effectively prevented the decrease in SOD, CAT, and GPx activities, which may be attributed to the scavenging of radicals by GIE, resulting in decreased formation of peroxides and a protection of these enzymes. 
Hence, it may be possible that the mechanism of hepatoprotection of GIE is due to its antioxidant effect.

GR is an antioxidant enzyme involved in the reduction of GSSG (an end-product of GPx reaction) to GSH. In ATDtreated rats, there was a marked depletion of GPx activity, leading to reduced availability of substrate for GR, thereby affecting the activity of GR. Oral treatment of GIE to ATDtreated rats restored the activity of GR, thus accelerating the conversion of GSSG to GSH and enhancing the detoxification of reactive metabolites by conjugation with GSH.

GSH is one of the most abundant nonenzymatic antioxidant biomolecules present in the tissues. ${ }^{41}$ Its functions are removal of free oxygen species such as $\mathrm{H}_{2} \mathrm{O}_{2}$, superoxide anions, and alkoxy radicals; maintenance of membrane protein thiols; and to act as a substrate for GPx and GSH $S$-transferase (GST). ${ }^{42}$ In the present study, decreased GSH levels in ATD-fed rats may be due to its increased utilization for augmenting the activities of GPx and GST. GSH levels depleted by ATD administration were significantly restored by GIE, either due to increased synthesis of GSH or by stimulation of GR activity.

In the present study, hepatotoxicity is characterized by marked diffuse granular degeneration, mild diffuse lymphocytic infiltration, and mild lobular disarray with multifocal individual cell pyknosis. Co-administration of GIE for 29 days protected the rat livers from isoniazid, rifampicin, and pyrazinamide-induced histopathological changes.

The hepatoprotective effect of GIE may thus be attributed to an underlying antioxidant activity that prevents the process of initiation and progress of hepatocellular injury. The effects of GIE were comparable with those of Liv.52, a herbal hepatoprotective that is much in clinical use.

In conclusion, the hepatoprotective effect of GIE in ATD-induced liver injury in rats appears to be related to the inhibition of LPO processes and to the prevention of GSH depletion. This study thus aims to bring about value addition to the health benefits of kokum, establish it as a "functional food," and promote its use as a culinary spice to enrich people's diets. In addition, it is cheap, readily available to all strata of society, and has medicinal properties attributed to it.

\section{Acknowledgments}

We acknowledge the All India Council for Technical Education (AICTE) (New Delhi, India) for providing grant-in-aid under its research promotion scheme for this study. We are grateful to Piramal Healthcare Limited (Mumbai, India) for providing animals for this study. We thank Sandoz Pvt Ltd (Mumbai, India) and Amsal Chem Pvt Ltd (Mumbai, India) for providing gift samples of antitubercular drugs.

\section{Disclosure}

The authors report no conflicts of interest in this work.

\section{References}

1. Lawn SD, Zumla AI. Tuberculosis. Lancet. 2011;378:57-72.

2. Corbett EL, Watt CJ, Walker N, et al. The growing burden of tuberculosis: global trends and interactions with the HIV epidemic. Arch Intern Med. 2003;163:1009-1021.

3. Tostmann A, Boeree MJ, Aarnoutse RE, de Lange WC, van der Ven AJ, Dekhuijzen R. Antituberculosis drug-induced hepatotoxicity: concise up-to-date review. J Gastroenterol Hepatol. 2008;23:192-202.

4. Khare CP. Indian Medicinal Plants: An Illustrated Dictionary, 2nd ed. New York, NY: Springer; 2007:278-279.

5. Shastri BN, editor. The wealth of India: a dictionary of Indian raw materials and industrial products, New Delhi, India: CSIR; 1956:101-103.

6. Jena BS, Jayaprakasha GK, Singh RP, Sakariah KK. Chemistry and biochemistry of (-)-hydroxycitric acid from Garcinia. J Agric Food Chem. 2002;50:10-22.

7. Devasagayam TPA, Tilak JC, Bapat MM, Mishra A. Antioxidant activity of Garcinia indica (kokam) and its syrup. Curr Sci. 2006;91:90-93.

8. Krishnamurthy N, Sampathu SR. Antioxidant principles of Kokum rind. J Food Sci Technol. 1988;25:44-45.

9. Yamaguchi F, Ariga T, Yoshimura Y, Nakazawa H. Antioxidative and anti-glycation activity of garcinol from Garcinia indica fruit rind. J Agric Food Chem. 2000;48:180-185.

10. Yamaguchi F, Saito M, Ariga T, Yoshimura Y, Nakazawa H. Free radical scavenging activity and antiulcer activity of garcinol from Garcinia indica fruit rind. J Agric Food Chem. 2000;48:2320-2325.

11. Pan MH, Chang WL, Lin-Shiau SY, Ho CT, Lin JK. Induction of apoptosis by garcinol and curcumin through cytochrome $\mathrm{c}$ release and activation of caspases in human leukemia HL-60 cells. J Agric Food Chem. 2001;49:1464-1474.

12. Rukachaisirikul V, Naklue W, Sukpondma Y, Phongpaichit S. An antibacterial biphenyl derivative from Garcinia bancana MIQ. Chem Pharm Bull. 2005;53:342-343.

13. Iinuma $\mathrm{M}$, Tosa $\mathrm{H}$, Tanaka $\mathrm{T}$, et al. Antibacterial activity of some Garcinia benzophenone derivatives against methicillin-resistant Staphylococcus aureus. Biol Pharm Bull. 1996;19:311-314.

14. Balasubramanyam K, Altaf M, Varier RA, et al. Polyisoprenylated benzophenone, garcinol, a natural histone acetyltransferase inhibitor, represses chromatin transcription and alters global gene expression. J Biol Chem. 2004;279:33716-33726.

15. Mantelingu K, Reddy BA, Swaminathan V, et al. Specific inhibition of p300-HAT alters global gene expression and represses HIV replication. Chem Biol. 2007;14:645-657.

16. Padhye S, Ahmad A, Oswal N, Sarkar FH. Emerging role of Garcinol, the antioxidant chalcone from Garcinia indica Choisy and its synthetic analogs. J Hematol Oncol. 2009;2:38-51.

17. Panda VS, Ashar HD. Antioxidant and hepatoprotective effects of Garcinia indica Choisy fruits in carbon tetrachloride-induced liver injury in rats. J Food Biochem. 36:240-247.

18. Padma VV, Suja V, Shyamala Devi CS. Hepatoprotective effect of Liv.52 on antitubercular drug-induced hepatotoxicity in rats. Fitoterapia. 1998;LXIX:520-522.

19. Tandon VR, Khajuria V, Kapoor B, Kour D, Gupta S. Hepatoprotective activity of Vitex negundo leaf extract against anti-tubercular drugs induced hepatotoxicity. Fitoterapia. 2008;79:533-538.

20. Lowry OH, Rosebrough NJ, Farr AL, Randall RJ. Protein measurement with the Folin phenol reagent. J Biol Chem. 1951;193:265-275. 
21. Webster D, Bignell AH, Attwood EC. An assessment of the suitability of bromocresol green for the determination of serum albumin. Clin Chim Acta. 1974;53:101-108.

22. Jendrassik L, Groff P. Estimation of bilirubin. Biochem. 1938;297: 81-89.

23. Ohkawa H, Ohishi N, Yagi K. Assay of lipid peroxidation in animal tissues by thiobarbituric acid reaction. Anal Biochem. 1979;95:351-358.

24. Ellman GL. Tissue sulphydryl groups. Arch Biochem Biophys. 1959;82:70-77.

25. Sun M, Zigman S. An improved spectrophotometric assay for superoxide dismutase based on epinephrine auto-oxidation. Anal Biochem. 1978;90:81-89.

26. Clairborne A. Catalase activity. CRS handbook of methods in oxygen radical research. In: Greenwald RA, editor. Boca Raton, FL: CRS Press; 1985:283-284.

27. Rotruck JT, Pope AL, Ganther HE, Hofeman DG, Hoekstra WG. Selenium: biochemical role as a component of glutathione peroxidase. Science. 1973;179:588-590.

28. Mohandas J, Marshal JJ, Duggin GG, Horvath JS, Tiller DG. Low activities of glutathione-related enzymes as factors in the genesis of urinary bladder cancer. Cancer Res. 1984;44:5086-5091.

29. Devarbhavi H, Dierkhising R, Kremers WK. Antituberculosis therapy drug-induced liver injury and acute liver failure. Hepatology. 2010;52:798-799.

30. Stork MC, Hoffman SR. Tuberculosis. Rom NW, Garay MS, editors Boston-New York-Toronto-London: Little Brown and Company; 1996 : 829.

31. Ellard GA, Gammon PT. Pharmacokinetics of isoniazid metabolism in man. J Pharmacokinet Biopharm. 1976;4:83-113.

32. Askgaard SD, Wilcke T, Dorring M. Hepatotoxicity caused by the combined action of isoniazid and rifampicin. Thorax. 1995;50: 213-214.
33. Hussain T, Gupta RK, Sweety K, et al. Evaluation of antihepatotoxic potential of Solanum xanthocarpum fruit extract against antitubercular drugs induced hepatopathy in experimental rodents. Asian Pac J Tropical Biomed. 2012;2:454-460.

34. Deepa PR, Varalakshmi P. Protective effect of low molecular weight heparin on oxidative injury and cellular abnormalities in adriamycin-induced cardiac and hepatic toxicity. Chem Biol Interact. 2003;146:201-210.

35. Charlton MR. Protein metabolism and liver disease. Baillieres Clin Endocrinol Metab. 1996;10:617-635.

36. Praneetha P, Rani VS, Kumar BS. Hepatoprotective activity of methanol extract of leaves of Marsilea minuta Linn Against $\mathrm{CCl}_{4}$ induced hepatic damage in rats. Global Journal of Pharmacol. 2011;5:164-171.

37. Tasduq SA, Peerzada K, Koul S, Bhat R, Johri RK. Biochemical manifestations of anti-tuberculosis drugs induced hepatotoxicity and the effect of silymarin. Hepatol Res. 2005;31:132-135.

38. Georgieva N, Gadjeva V, Tolekova A. New isonicotinoylhydrazones with SSA protect against oxidative hepatic injury of isoniazid. Trakia J Sci. 2004;2:37-43.

39. Saraswathy SD, Suja V, Prema G, Shyamala Devi CS. Effect of Liv.100 against antitubercular drugs induced hepatotoxicity in rats. Indian $J$ Pharmacol. 1998;30:233-238.

40. Ji LL, Stantman FW, Lardy HA. Antioxidant enzyme systems in rat liver and skeletal muscle. Arch Biochem Biophys. 1988;263:150-160.

41. Meister A. New aspects of glutathione biochemistry and transport selective alterations of glutathione metabolism. Nutr Rev. 1984;42: $397-400$.

42. Townsend DM, Tew KD, Tapiero H. The importance of glutathione in human disease. Biomed Pharmacother. 2003;57:145-155.
Botanics: Targets and Therapy

\section{Publish your work in this journal}

Botanics: Targets and Therapy is an international, peer-reviewed, open access journal focusing on the discovery and development of active compounds based upon or found naturally occurring in the plant kingdom that may have therapeutic potential in any disease state. The manuscript management system is completely online and includes a very

\section{Dovepress}

quick and fair peer-review system. Visit http://www.dovepress.com/ testimonials.php to read real quotes from published authors. 